Supporting information for:

\title{
Longevity expectations for polymers in medical devices demand new approaches to evaluating their biostability
}

\author{
K. A. Chaffin \\ Corporate Science and Technology, Medtronic, plc. Minneapolis, MN 55432 \\ kim.chaffin@medtronic.com
}

Running an experiment over a period of almost 9 years requires careful controls, where the size exclusion chromatography experiment (SEC) utilized for the measurement of molar mass, the indicator of the extent of reaction, experienced multiple cycles of preventative maintenance and column changes. The method used for the SEC experiments were described in Chaffin et al. [Macromolecules 2012] and utilized both a light scattering detector and polystyrene standards.

Figure S1 demonstrated the stability of the molar mass measurement on a compression molded slab of poly(dimethylsiloxane) urethane, periodically sampled and retuned to storage in a $-80^{\circ} \mathrm{C}$ freezer. The plot shows the results of the frozen sample $\left(M_{n}(t=0) / M_{n}(t)\right)$ measured at each date, indicating good stability of the measurement over the course of the experiment.

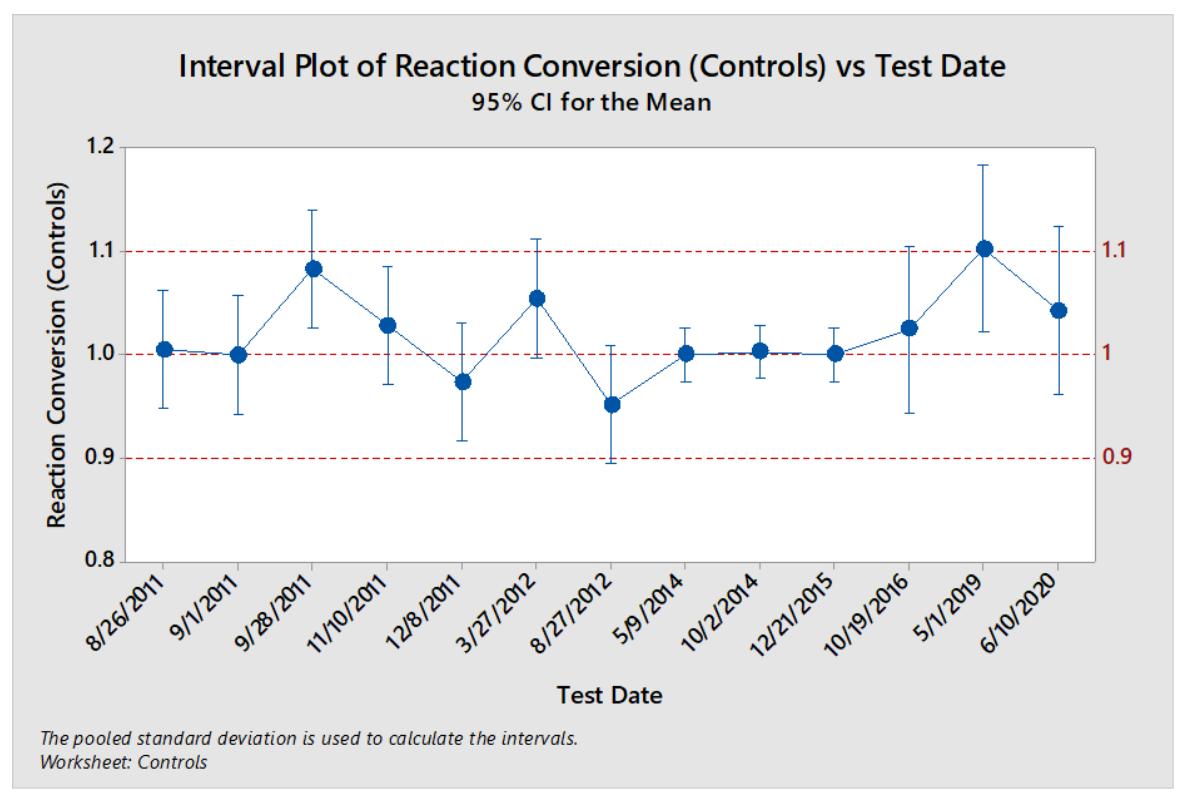

Figure S1: A control sample was analyzed by Size Exclusion Chromatography (SEC) at each time point a sample exposed to water was evaluated. The control sample was stored dry and in a freezer at $-80^{\circ} \mathrm{C}$, for the experiment duration. The variance of the data described correlates well to the typical $\pm 10 \%$ uncertainty for the SEC equipment. 
A statistical analysis was completed on the accelerated ( 1 year, 2.5 year) and the real time $\left(37^{\circ} \mathrm{C}\right.$ ) datasets, where the analysis verified the linear fit and a y-intercept equivalent to one. The variability in the slope, 95\% confidence limits on the slope and the $p$-values of the slope comparisons were calculated and are shown in Table S1. The slopes of each dataset were statistically different from zero and from each other ( $p$ value $<0.0001$ ). Despite the different slopes, the molar mass prediction for ten years of implant time are practically equivalent, giving molar mass predictions for each of the datasets that range from 18 to 24 kDaltons, values which have shown equivalent and severely compromised in mechanical performance. ${ }^{1}$

TABLE S1: Statistical analysis of the slope and prediction limits of data: real time, published accelerated, extended accelerated. The predicted molar mass at 10 years was calculated from eq 1 in the manuscript.

\begin{tabular}{|l|c|c|c|c|c|c|c|}
\hline \multicolumn{1}{|c|}{ Dataset } & $\begin{array}{c}\text { Data } \\
\text { Collection } \\
\text { Duration } \\
\text { (years) }\end{array}$ & $\begin{array}{c}\text { Prediction } \\
\text { Duration } \\
\text { (years) }\end{array}$ & $\begin{array}{c}\text { Estimated } \\
\text { Slope }\end{array}$ & $\begin{array}{c}\text { Slope 95\% } \\
\text { Lower } \\
\text { Confidence } \\
\text { Bound }\end{array}$ & $\begin{array}{c}\text { Slope 95\% } \\
\text { Upper } \\
\text { Confidence } \\
\text { Bound }\end{array}$ & $\begin{array}{c}\text { P value } \\
\text { (Slopes are } \\
\text { statistically } \\
\text { different) }\end{array}$ & $\begin{array}{c}\text { Mean Molar } \\
\text { mass @ 10 } \\
\text { years } \\
\text { (kDaltons) } \\
\mathbf{M}_{\mathrm{n}}(\mathbf{t}=\mathbf{0})=48\end{array}$ \\
\hline $\begin{array}{l}\text { Real time } \\
\text { exposure @ } \\
\mathbf{3 7} \mathbf{~}^{\circ} \mathbf{C}\end{array}$ & 8.8 & 8.8 & 0.1035 & 0.0979 & 0.1092 & $\begin{array}{c}\text { Reference } \\
\text { Level }\end{array}$ & $\begin{array}{c}23.6 \pm 0.9 \\
(51 \% \\
\text { decrease) }\end{array}$ \\
\hline $\begin{array}{l}\text { Published } \\
\text { Accelerated }\end{array}$ & 1 & 6.4 & 0.1706 & 0.1634 & 0.1778 & $<0.0001$ & $\begin{array}{c}17.8 \pm 0.7 \\
(63 \% \\
\text { decrease) }\end{array}$ \\
\hline $\begin{array}{l}\text { Extended } \\
\text { Accelerated }\end{array}$ & 2.5 & 16.9 & 0.1279 & 0.1206 & 0.1351 & $<0.0001$ & $\begin{array}{c}21.1 \pm 0.9 \\
(56 \% \\
\text { decrease) }\end{array}$ \\
\hline
\end{tabular}

Equally important to the prediction of reaction extent (molar mass) at ten years is the experimental time required to make that prediction. A second statistical analysis was directed at assessing the real time dataset, a dataset that compares to the current biostability standards that combines an in vitro oxidation challenge with a six month in vivo real time exposure. In this analysis, tabulated in Table S2, a sensitivity assessment was performed, where the real time data set was evaluated for the strength of the degradation signal as a function of experimental time. The signal strength was calculated by comparing the extent of reaction measured at a given experimental time compared to the control, tabulated as a percent change from the no-reaction (slope $=0$ ) control. While increasing the duration of the real time experiment did improve the ability to detect a signal (e.g. $9 \%$ to $12 \%$ signal increase when the reaction time was extended from 6 months to 1 year), the impact was modest. By contrast, when an accelerated dataset was included, the strength of the degradation signal increased from $12 \%$ to $110 \%$ for a constant experimental time of one year. For an equivalent detection signal, almost 9 years of real time testing was required. An additional advantage of accelerated testing is that the precision of the extrapolated 10-year mean molar mass estimate (range of the upper and lower confidence interval) is significantly increased. 
Table S2: Strength of the degradation signal for experimental timeframe ranging from six months to two and a half years, where the magnitude of the degradation signal for real time experiments are compared to accelerated experiments.

\begin{tabular}{|c|c|c|c|c|c|c|}
\hline Dataset & $\begin{array}{l}\text { Data } \\
\text { Collection } \\
\text { Duration } \\
\text { (years) }\end{array}$ & $\begin{array}{c}\text { Prediction } \\
\text { Duration } \\
\text { (years) }\end{array}$ & $\begin{array}{c}\text { Strength of } \\
\text { signal } \\
\text { (\% change } \\
\text { in average } \\
\text { extent of } \\
\text { reaction) }\end{array}$ & $\begin{array}{c}10 \text { year } \\
\text { Extrapolated } \\
\text { Lower } \\
\text { Confidence } \\
\text { Bound (LCB) on } \\
\text { Signal Strength } \\
\text { (\% change in } \\
\text { average extent } \\
\text { of reaction) }\end{array}$ & $\begin{array}{c}10 \text { year } \\
\text { Extrapolated } \\
\text { Upper } \\
\text { Confidence } \\
\text { Bound (UCB) } \\
\text { on Signal } \\
\text { Strength } \\
\text { (\% change in } \\
\text { average extent } \\
\text { of reaction) }\end{array}$ & $\begin{array}{c}\text { Extrapolated } \\
\text { mean molar } \\
\text { mass range } \\
\text { @ } 10 \text { yrs } \\
\text { (UCB-LCB) }\end{array}$ \\
\hline $\begin{array}{l}\text { Real time } \\
\text { exposure @ } \\
37^{\circ} \mathrm{C}\end{array}$ & 0.5 & 0.5 & $9 \%$ & $73 \%$ & $219 \%$ & $\begin{array}{c}15-28 \\
\text { kDaltons } \\
(145 \%)\end{array}$ \\
\hline $\begin{array}{l}\text { Real time } \\
\text { exposure @ } \\
37^{\circ} \mathrm{C}\end{array}$ & 1 & 1 & $12 \%$ & $99 \%$ & $155 \%$ & $\begin{array}{c}19-24 \\
\text { kDaltons } \\
(55 \%)\end{array}$ \\
\hline $\begin{array}{l}\text { Real time } \\
\text { exposure @ } \\
37^{\circ} \mathrm{C}\end{array}$ & 2.5 & 2.5 & $27 \%$ & $98 \%$ & $109 \%$ & $\begin{array}{c}21-26 \\
\text { kDaltons } \\
(42 \%)\end{array}$ \\
\hline $\begin{array}{l}\text { Real Time } \\
\text { exposure @ } \\
37^{\circ} \mathrm{C}\end{array}$ & 8 & 8 & $91 \%$ & $99 \%$ & $155 \%$ & $\begin{array}{c}23-24 \\
\text { kDaltons } \\
(11 \%)\end{array}$ \\
\hline Accelerated & 1 & 6.4 & $109 \%$ & $163 \%$ & $178 \%$ & $\begin{array}{c}17-18 \\
\text { kDaltons } \\
(14 \%)\end{array}$ \\
\hline Accelerated & 2.5 & 16.9 & $217 \%$ & $142 \%$ & $158 \%$ & $\begin{array}{c}20-22 \\
\text { kDaltons } \\
(15 \%)\end{array}$ \\
\hline
\end{tabular}

The mechanical response of the aged polymer was independent of the temperature exposure pathway. Tensile properties were characterized for each of the datapoints collected over the first year of accelerated exposure in phosphate buffered saline (PBS). The one year $37^{\circ} \mathrm{C}$ real time aged data point demonstrated a comparable molar mass to the 8 week $85^{\circ} \mathrm{C}$ sample $(\sim 42 \mathrm{~kg} / \mathrm{mole}$ vs. $\sim 40 \mathrm{~kg} / \mathrm{mole})$ in the reduced time analysis that is the output of the Arrhenius treatment. An expanded version of Figure 13 from Chaffin et al. is shown in Figure S2, where two datasets having similar molar mass are highlighted in a box. ${ }^{1}$ At each of these time points, tensile bars $(n=15)$ were evaluated. The average tensile toughness for the sample set exposed for 52 weeks at $37^{\circ} \mathrm{C}$ had an average tensile toughness of $6970 \pm 690 \mathrm{MPa}$ and that for the sample set exposed for 8 weeks at $85^{\circ} \mathrm{C}$ had an average tensile toughness of $6780 \pm 880 \mathrm{MPa}$, values are within $3 \%$ of each other. The close agreement of the 
mechanical response data, when matching molar mass, suggests that both degradation pathways $\left(37^{\circ} \mathrm{C}\right.$ for one year and $85^{\circ} \mathrm{C}$ for 8 weeks) result in comparable mechanical properties.

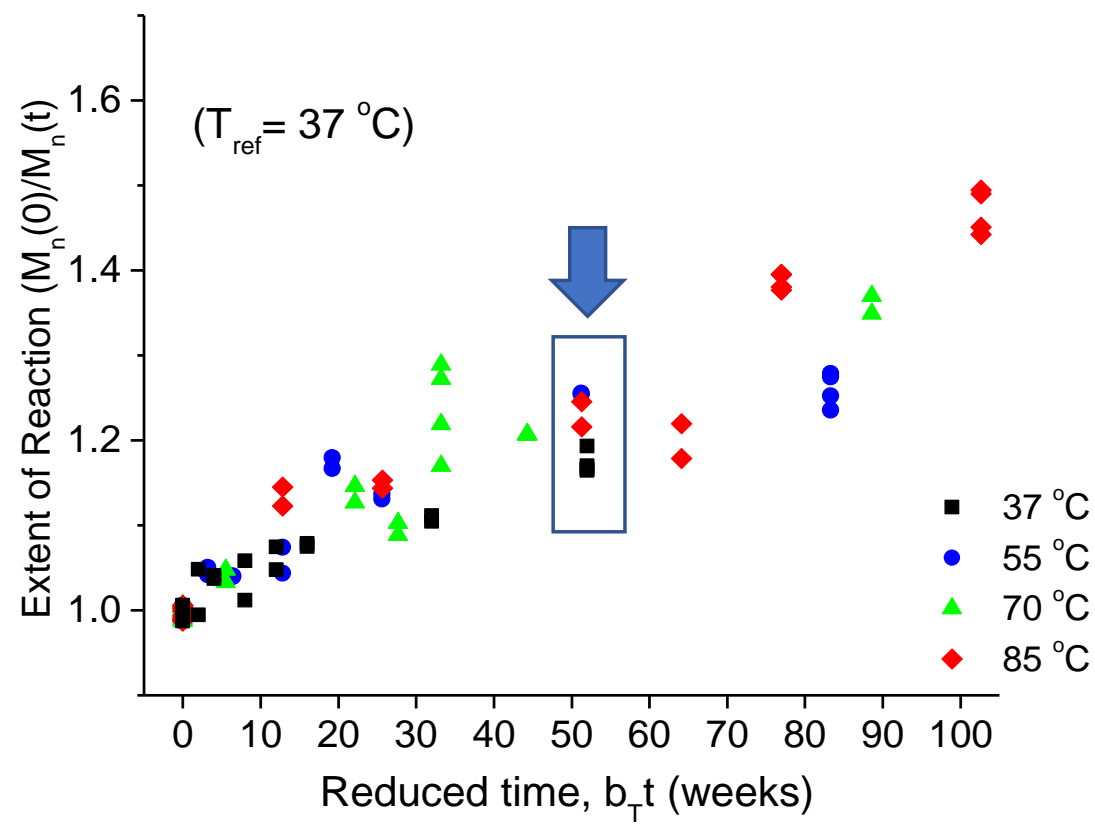

Figure S2: This reduced time plot is reproduced from a Chaffin et al. in an expanded form. The mechanical comparison was performed on the $37^{\circ} \mathrm{C}$ and $85^{\circ} \mathrm{C}$ samples highlighted in the box.

${ }^{1}$ Chaffin, K.A., Buckalew, A.J., Schley, J.L., Chen, Z, Jolly, M., Alkatout J.A., Miller, J.P., Undereker, D.F., Hillmyer, M.A., Bates, F.S. Influence of water on the structure and properties of PDMS containing multiblock polyurethanes Macromolecules 2012, 45, 9110-9120. 